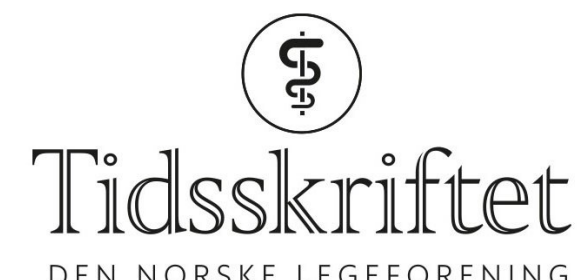

DEN NORSKE LEGEFORENING

\title{
Elektrikerlærling skadet av strømgjennomgang
}

NOE Å LAERE AV

\section{LARS OLE GOFFENG}

E-post: lars.goffeng@stami.no Statens arbeidsmiljøinstitutt

Lars Ole Goffeng (f. 1955) er ph.d. og psykolog med mangeårig erfaring med problemstillinger omkring strømulykker.

Forfatter har fylt ut ICMJE-skjemaet og oppgir ingen interessekonflikter.

\section{DAG RUNE STORMOEN}

Dilling

Dag Rune Stormoen (f. 1985) er lege i spesialisering i allmennmedisin og har klinisk erfaring med pasienter som har vært eksponert for strøm.

Forfatter har fylt ut ICMJE-skjemaet og oppgir ingen interessekonflikter.

\section{KAJ BO VEIERSTED}

Statens arbeidsmiljøinstitutt

Kaj Bo Veiersted (f. 1953) er dr.med. og spesialist $i$ arbeidsmedisin med mangeårig erfaring med problemstillinger omkring strømulykker.

Forfatter har fylt ut ICMJE-skjemaet og oppgir ingen interessekonflikter.

Strømgjennomgang fra lavspenning kan gi forskjellige typer og grader av helseutfall, som hjerterytmeforstyrrelser og indre forbrenninger. Sannsynligheten for skade er normalt avhengig av strømstyrke, spenningsnivå, strømvei gjennom kroppen og eksponeringsvarighet. Vi beskriver en pasient utsatt for strømgjennomgang, der antatt lavt skadepotensial fikk større kliniske konsekvenser enn forventet.

En elektrikerlærling i 2o-årene fikk strømgjennomgang da han skulle montere en stikkontakt i en veggboks i taket over en himling. Han arbeidet med armene over hodet $\mathrm{i}$ toppen av en gardintrapp, med føttene ca. $180 \mathrm{~cm}$ over gulvet. Begge tuppene på tommelfingrene kom i kontakt med strømførende poler bak stikkontakten, og han fikk strømgjennomgang fra hånd til hånd, med sannsynlig strømvei via hjerteregionen. Nettsystemet på arbeidsstedet tilsier at spenningen var $230 \mathrm{~V}$. Han falt ikke ned, men ble antagelig frigjort øyeblikkelig, siden grepet om kontakten ikke var lukket. Han opplevde at strømgjennomgangen kun varte et kort øyeblikk. Etter strømgjennomgangen var han omtåket og trengte noen minutter å komme seg på, før han meldte fra til en kollega, som kjørte ham til Legevakten.

Antallet potensielt alvorlige strømulykker blant elektrikere i Norge er estimert til å være ca. 3 ooo årlig, basert på subjektiv vurdering av skadepotensialet (1). Tilsvarende nivå er funnet i Sverige og Danmark (2). De fleste av disse medfører ikke kontakt med helsevesenet, men 
elektrobransjen selv er oppmerksom på mulige farer ved denne typen eksponering. Derfor er det utarbeidet anbefalinger for når og på hvilken måte personer utsatt for strømgjennomgang bør følges opp av helsevesenet i akuttfasen (3).

Strømulykker kan potensielt medføre alvorlige akutteffekter, fortrinnsvis på hjerte, nervesystem, hud og muskel- og skjelettsystem (3-5). Ved strømgjennomgang arm til arm fra lavspenning er de viktigste mulige komplikasjonene i en akuttfase påvirkning av hjertet, dype muskelskader på grunn av vevsoppvarming (indre forbrenning), nerveskader, fallskader eller hel/delvis overriving av muskelfester $(3,6)$. Ved større muskelskade, rabdomyolyse, frigjøres store mengder myoglobin og elektrolytter fra skadet muskel, hvilket kan medføre nyresvikt. Sannsynlighet for muskelskader på grunn av vevsoppvarming regnes normalt som begrenset ved lavspenningsgjennomgang, hvis man ikke henger fast til strømkilden på grunn av kramper. De potensielt mer livsfarlige høyspenningsulykkene kan ha betydelig større virkninger, herunder brannskader og rabdomyolyse.

På Legevakten viste elektrokardiogram (EKG) normal sinusrytme uten arytmitegn. Pasienten følte seg utilpass og måtte sitte litt ned. Han hadde ubehag i høyre hånd med utstråling til hals, men det var ikke rapportert om hudforandringer, nummenhet i hånd eller hjertebank. Siden han hadde normale EKG-funn og ikke følte seg syk, ble det vurdert å sende ham hjem etter kort tid. Imidlertid kom det frem at pasienten fra tidligere hadde vært plaget med hjertebankanfall, der det etter utredning var blitt konkludert med nodal reentrytakykardi. Fire år før ulykkestidspunktet hadde han gjennomgått en vellykket ablasjonsbehandling.

Grunnet tidligere sykehistorie konfererte legevaktlegen med bakvakt på medisinsk avdeling ved sykehuset, og pasienten ble innlagt til observasjon på intensivavdeling med overvåking under hele innleggelsen.

Blodprøver tatt 2 t 45 minutter etter ulykken viste forhøyet total kreatinkinase (CK) i serum på $37669 \mathrm{U} / \mathrm{l}$ ( referanseområde 50-400) og s-ALAT på $201 \mathrm{U} / \mathrm{l}$ (10-70) (tab 1). Øvrige prøver var innen referanseområdet (7). Det forelå blodprøvesvar tatt hos fastlege fra før ulykken. Disse viste bl.a. normal total CK.

\section{Tabell 1}

Utvalgte blodprøveresultater før ulykken og i akuttfasen. Øvrige prøver ble tatt og lå innenfor referanseområdet enten både før og etter (b-leukocytter, b-hemoglobin, btrombocytter, s-albumin, s-alkalisk fosfatase, s-natrium), eller etter, men ble ikke tatt før ulykken (s-CRP, total s-bilirubin, s-GT, s-amylase i pancreas, p-klorid).

\begin{tabular}{|c|c|c|c|c|c|c|c|c|}
\hline \multicolumn{3}{|c|}{ Tidspunkt } & \multirow{2}{*}{$\begin{array}{c}\text { 12:45 } \\
0 t\end{array}$} & \multirow{2}{*}{$\begin{array}{c}15: 30 \\
2 t \\
45 \mathrm{~m} \\
\end{array}$} & \multirow{2}{*}{$\begin{array}{c}\text { 21:30 } \\
8 \mathrm{t} \\
45 \mathrm{~m} \\
\end{array}$} & \multirow{2}{*}{$\begin{array}{c}\text { o8:oo } \\
19 \mathrm{t} \\
15 \mathrm{~m} \\
\end{array}$} & \multirow{2}{*}{$\begin{array}{c}\text { o8:0o } \\
43 \mathrm{t} \\
15 \mathrm{~m} \\
\end{array}$} & \\
\hline & & & & & & & & \\
\hline & & $\begin{array}{c}1 \text { md. } \\
\text { før } \\
\text { ulykken }\end{array}$ & Ulykken & & & $\begin{array}{c}2 . \\
\text { dag }\end{array}$ & $\begin{array}{c}3 . \\
\text { dag }\end{array}$ & $\begin{array}{l}10 . \\
\text { dag }\end{array}$ \\
\hline Analyser & Referanseområde & & & & & & & \\
\hline $\begin{array}{l}\text { Total s-CK } \\
(\mathrm{U} / \mathrm{I})\end{array}$ & $50-400^{1,2}$ & 109 & & $\begin{array}{c}37 \\
669^{*} \\
\end{array}$ & $\begin{array}{c}26 \\
351^{*}\end{array}$ & $\begin{array}{c}19 \\
217^{*} \\
\end{array}$ & $\begin{array}{c}9 \\
660^{*} \\
\end{array}$ & 238 \\
\hline $\begin{array}{l}\text { S-troponin } \\
\mathrm{T}(\mathrm{ng} / \mathrm{l})\end{array}$ & $<14$ & & & $<10$ & & & & \\
\hline $\begin{array}{l}\text { S-kreatinin } \\
(\mu \mathrm{mol} / \mathrm{l})\end{array}$ & $60-100$ & 99 & & 87 & 83 & 80 & & \\
\hline $\begin{array}{l}\text { S-urinstoff } \\
\text { (urea) } \\
\text { (mmol/l) }\end{array}$ & $3,2-8,1^{1,2}$ & 4,8 & & 5,7 & & $2,8^{*}$ & & \\
\hline $\begin{array}{l}\text { S-ASAT } \\
(\mathrm{U} / \mathrm{I})\end{array}$ & $15-45^{1}$ & & & & $420^{*}$ & & & \\
\hline
\end{tabular}




\begin{tabular}{|c|c|c|c|c|c|c|}
\hline & Tidspunkt & & $12: 45$ & $15: 30$ & 21:30 & o8:00 \\
\hline $\begin{array}{l}\text { S-ALAT } \\
(U / I)\end{array}$ & $10-70^{1}$ & & & $201^{*}$ & & $149^{*}$ \\
\hline $\begin{array}{l}\text { P-kalium } \\
\text { (mmol/l) }\end{array}$ & $3,5-4,4$ & & & 4,0 & $3,3^{*}$ & 3,9 \\
\hline $\begin{array}{l}\text { S-kalsium, } \\
\text { albkorr. } \\
(\mathrm{mmol} / \mathrm{l})\end{array}$ & $2,17-2,47$ & 2,31 & & 2,32 & $2,07^{*}$ & \\
\hline
\end{tabular}

Utenfor referanseområdet

${ }^{1}$ Referanseområdet for menn

${ }^{2}$ Referanseområdet for aldersgruppen 18-49 år

Pasienten hadde innlagt kateter første døgn. Urinstiks ble tatt tre ganger samme dag som strømulykken og var alle ganger negativ for glukose, ketoner, leukocytter, albumin og blod. Det ble ikke bemerket mørk urin på noe tidspunkt, og urinen ble ikke mikroskopert.

Forhøyet total s-CK avspeiler affisert muskelvev og kan forekomme ved en rekke ulike forhold, deriblant krampeanfall, fysiske traumer eller skader på muskler etter kraftig trening, muskulær iskemi eksempelvis etter CO-forgiftning og ved primære muskelsykdommer som Duchennes muskeldystrofi. Forhøyet total s-CK kan være forårsaket både av virus- og bakterielle infeksjoner og av en del medisiner, som nevroleptika (malignt nevroleptikasyndrom), sykliske antidepressiver eller antihistaminer. Det samme gjelder toksiske stoffer som eksempelvis alkohol, barbiturater eller amfetamin (8). Forventet CK$\emptyset \mathrm{kning}$ varierer avhengig av årsak (9).

Lett til moderat forhøyede ALAT-verdier kan ses ved en rekke tilstander, spesielt i lever, men også ved skader i skjelettmuskulatur, da samtidig alltid med høyere verdier av s-ASAT og også forhøyede verdier av total s-CK $(7,10)$.

Myoglobinuri kan være en del av det kliniske bildet ved rabdomyolyse, men i visse materialer gjelder det under 1/5 av tilfellene (11). Dette er derfor et usikkert mål som er avhengig av svært rask frigjøring i skadede muskler. S-myoglobin normaliseres innen 24 timer (8), og u-myoglobin er avhengig av væskegjennomstrømning, personens vekt og ikke minst tid siden skaden samt av at nyrenes kapasitet overskrides $(8,12)$.

Prøveresultatene kunne tyde på muskelskade (rabdomyolyse) til tross for kort varighet av strømgjennomgangen. For å forebygge nyreskade ble han innlagt og behandlet med væsketilførsel (forsert alkalisk diurese). Totalt gitt saltvann var $6250 \mathrm{ml}$ første døgn, med diurese målt fra kl 18 innleggelsesdagen til kl 6 neste morgen på $3190 \mathrm{ml}$. Seks timer etter at behandling ble igangsatt, var total s-CK 26351 U/l. Etter 24 timer var den 18338 U/l. S-ASAT var $420 \mathrm{U} / \mathrm{l}$ og fortsatt forhøyet, mens p-kalium og s-kalsium lå noe lavt ni timer etter ulykken, dvs. under behandlingen med forsert diurese.

Ellers lå øvrige verdier (b-leukocytter, b-hemoglobin, b-trombocytter, s-albumin, skreatinin, s-alkalisk fosfatase, s-natrium) innenfor referanseområdet både før og etter ulykken.

Ved utskrivning to dager etter innleggelsen fremsto han som klinisk upåfallende. Alle symptomer (ubehag i høyre hånd med utstråling til hals) var gått helt vekk, men han hadde fortsatt forhøyet total s-CK på 9 66o U/l ( ref. 50-40o) og fikk beskjed om at rikelig væskeinntak i noen dager fremover var viktig. Poliklinisk kontroll etter ti dager viste normal verdi av total s-CK( $\operatorname{tab} 1)$.

\section{Diskusjon}

I denne kasuistikken beskrives en strømeksponert pasient der de innledende vurderingene av pasientens gode allmenntilstand, ulykkesforløp og antatt strømeksponering lett kunne ha resultert i manglende utredning og overvåking. Utvidede prøveresultater viste likevel at det var indikasjoner for forebygging av nyreskade på grunn av muskelaffeksjon. Siden 
prøver fra før ulykken viste normale resultater og man sto overfor en formodet opplagt utløsende årsak, ble det ikke gjort ytterligere differensialdiagnostiske overveielser.

Pasienten beskriver ikke kramper som kunne ha holdt ham til strømkretsen, sterke muskelkontraksjoner eller fall fra gardintrappen der han arbeidet. Ved så kortvarig eksponering for lavspenningsstrøm som det her syntes å være snakk om, betraktes skade som følge av vevsoppvarming normalt som mindre sannsynlig. Elektrobransjen omtaler ofte slike eksponeringer som «karameller».

Ved vurdering av strømulykker bør strømgjennomgangen beskrives slik at opplysningene er relevante for senere eksponeringsvurderinger. Stikkord er strømtype, spenningsnivå, sannsynlig strømvei gjennom kroppen og opplevd eller observert varighet av hendelsen. Funn fra undersøkelser i akuttfasen som kan gi holdepunkter for å supplere pasientens beskrivelse av eksponeringen, som kramper i armer eller ben, kontaktpunkters overflate og fuktighet (som påvirker motstand) samt hudforandringer, bør også inkluderes (2).

Vanligste type strømulykke er vekselstrømgjennomgang fra lavspenning-230 V eller $400 \mathrm{~V}$ - med en frekvens på $50 \mathrm{~Hz}$. Men særlig i arbeidslivet benyttes også likestrøm. Likestrøm og vekselstrøm har noe ulik effekt på mennesker. Den viktigste forskjellen er at vekselstrømmens frekvens på $50 \mathrm{~Hz}$ kan bidra til tetaniske muskelkontraksjoner som, hvis man holder rundt en strømleder, kan forårsake at man blir «hengende fast» til strømlederen. Dette vil øke varigheten av strømgjennomgangen og dermed risiko for vevsskade, herunder muskelskader. Særlig kroppsvev langs strømveien med stor motstand, som f.eks. knokler og sener, varmes opp. Dette gjør områder nær ledd- og muskelfester sårbare for skade (13). Likestrømgjennomgang medfører normalt ikke kramper av betydning og vil derfor normalt få kortere varighet enn en vekselstrømgjennomgang. Ved lynnedslag eller andre høyspenningsulykker betyr eksponeringstype og varighet mindre, da overføres uansett store energimengder.

For vurdering av mulige muskelskader trengs oppfølging ved avvikende total s-CK, som primært finnes i skjelettmuskulatur og myokard, men også i hjerne, tarm, nyre, thyreoidea og prostata. Enzymet kreatinkinase består av polypeptidkjeder som kan være av to typer: B og M. Total CK måler tre isoenzymer: CK-BB (hjernetype), CK-MB (hjertemuskeltype markør for infarkt) og CK-MM (skjelettmuskeltype). Av isoenzymene er det bare CK-MB som måles rutinemessig. Normalområdet for total s-CK hos menn 18-49 år ligger omkring 50-40o U/l, noe varierende mellom laboratorier. Normalverdi korrelerer med muskelmassen, og muskelarbeid kan medføre betydelig stigning i total s-CK, slik at selv moderat arbeid øker aktiviteten med $50 \%$ (14).

Under hele det inneliggende forløpet så vi hos denne pasienten sterkt forhøyede verdier av total s-CK, som blant annet kan forekomme ved utbredte skader på muskelvev/rabdomyolyse og ved store myokardinfarkter. Undersøkelse av total s-CK er derfor indisert ved utredning og monitorering av muskelskader og vurdering av behandlingsindikasjon ved rabdomyolyse $(8,12)$. Serumkonsentrasjonen av total CK avspeiler i høy grad mengden av det affiserte muskelvevet, og flere miljøer bruker 10 ooo U/1 som grenseverdi for å iverksette forsert diurese $(15,16)$. Hos kritisk syke pasienter med utbredte skader på muskelvev har kontroll av p-myoglobin større sensitivitet og spesifisitet enn kontroll av s-CK for vurdering av risiko for akutt nyresvikt (17). P-myoglobin ble ikke kontrollert hos denne pasienten.

Mest mulig nøyaktig tidsangivelse for eksponeringen gjør det lettere å tolke total s-CK, siden nivået ved en muskelskade innledningsvis ligger i normalområdet før den begynner å stige etter 2-12 timer (18). Etter rundt 24 timer når den maksimalt nivå $(8,19)$, er stabil i opptil tre døgn (8), for deretter gradvis å reduseres og normaliseres etter 2-3 (19) til 4-5 døgn (8). Det er stor variasjon i dette, avhengig av hydreringsgrad og nyrefunksjon. Tidspunkt for skade og prøvetaking er dermed viktig ettersom prøver tatt for kort tid etter skaden vil ligge i normalområdet, mens verdiene allerede kan ha begynt å synke etter omkring to døgn. Denne pasienten hadde en stigning i total s-CK etter 2 t 45 minutter. 
Variasjonen tilsier at det bør vurderes å ta flere prøver i løpet av det første halve døgnet etter skaden for sikrest mulig å fange opp en stigning og eventuelt iverksette behandling.

Å få dokumentert økt total s-CK i tide er også viktig dersom helseproblemer knyttet til armene skulle oppstå på et senere tidspunkt og det er grunn til å vurdere om dette er en yrkesskade i kjølvannet av den tidligere ulykken.

Pasientens tidligere sykehistorie bidro i dette tilfellet til at det ble gjort videre undersøkelser, som i neste omgang førte til innleggelse og behandling. Den innledende blodprøven var derfor avgjørende for at pasienten fikk den behandlingen han trengte for å komme best mulig fra denne ulykken.

Ved mistanke om akutt myokardskade, spesielt ved sannsynlig strømvei via brystregionen eller ved brystsmerter i kjølvannet av ulykken, bør måling av troponin T (eller I) benyttes, eventuelt med tillegg av CK-MB. Hos denne pasienten lå troponinnivået innenfor referanseverdien på < 14 ng/l (99-prosentilen) ved målingen fire timer etter ulykken ( $<10$ $\mathrm{ng} / \mathrm{l}$ ). Resultatene peker dermed i retning av at det var mer tverrstripet muskulatur (pga. forhøyet total s-CK) enn hjertemuskelen som var påvirket ved denne ulykken. Dette støttes ytterligere av at EKG ikke ga holdepunkter for rytmeforstyrrelser. Ut fra prøvedata har det derfor mest sannsynlig ikke vært økt risiko for hjertekomplikasjoner på bakgrunn av denne hendelsen.

Blodprøvene etter ulykken peker i retning av sikre tegn på muskelpåvirkning, selv om dette var uventet ut ifra de kliniske funnene. Strømeksponeringen kan derfor i realiteten ha vært mer alvorlig enn den i utgangspunktet ble beskrevet som. Men det kan også bety at terskelen for muskelaffeksjon er lavere enn antatt, og derfor ofte overses og underbehandles. Funnet i startfasen med samtidig normal s-kalium og høy total s-CK var overraskende. Det har vi problemer med å forklare. Normalt følger de hverandre ved celleskade (20). Rabdomyolyse er en kjent komplikasjon ved høyspenningsulykker (8, 21), men vi har ikke kunnskap om at dette tidligere er beskrevet etter strømgjennomgang fra lavspenning.

Det er tidligere publisert anbefalinger for undersøkelser av strømskadede på sykehus (3).Vi anbefaler at de akuttmedisinske avdelingene på norske sykehus ser nærmere på disse ved utforming av interne prosedyrer.

\section{Konklusjon}

Kasuistikken viser at muskelaffeksjon etter strømulykker kan finne sted ved strømulykker av mindre alvorlighetsgrad enn man hittil har antatt. Videre kan beslutning om innleggelse og overvåking i slike saker ikke gjøres på grunnlag av risiko for hjertekomplikasjoner alene, ettersom vi her ser et eksempel på skjelettmuskelaffeksjon uten tegn på hjerteaffeksjon. Total CK i serum er en viktig markør for vurdering av muskelskade. Det er avgjørende å vurdere tidspunkt for prøvetaking i forhold til ulykkestidspunkt, slik at eventuell skade fanges opp tidligst mulig. Ved normale funn innenfor de første 5-6 timene etter skade bør prøvetaking gjentas etter klinisk vurdering på grunn av latenstiden for stigning, og uansett etter 24 timer $(8,19)$. Dette skal sikre at maksimalverdien for total s-CK blir fanget opp og hindre at eventuell skade blir oversett.

\section{LITTERATUR:}

1. Goffeng LO, Veiersted KB, Moian R et al. Forekomst og forebygging av strømulykker i arbeidslivet. Tidsskr Nor Lægeforen 2003; 123: 2457 - 8. [PubMed]

2. Goffeng LO, Veiersted KB. Förebyggande arbete - erfarenheter från Norge (kapittel 11). I: Gunnarsson L-G, Thomée S, Jakobsson K, red. Elolyckor i arbetet. Arbete och hälsa. Vetenskaplig skriftserie, Arbetsoch miljömedicin. Göteborg: Göteborgs universitet, 2017; 51: 79 - 95.

3. Veiersted KB, Goffeng LO, Moian R et al. Akutte og kroniske skader etter strømulykker. Tidsskr Nor 
Lægeforen 2003; 123: 2453 - 6. [PubMed]

4. Lippestad C, Erikssen J, Vaagenes P et al. Strømskader. Patofysiologi og behandlingsprinsipper. Tidsskr Nor Lægeforen 1990; 110: 948 - 52. [PubMed]

5. Kaergaard A. Senfølger efter elulykker. Ugeskr Laeger 2009; 171: 993 - 7. [PubMed]

6. Veiersted KB, Goffeng LO, Tynes T. Senfølger av lavspent strømgjennomgang. Rotatortendinose, hørselstap og mulig neuropsykologisk funksjonstap. Tidsskr Nor Lægeforen 1997; 117:3363 - 5 . [PubMed]

7. Rustad P, Felding P, Franzson L et al. The Nordic Reference Interval Project 20oo: recommended reference intervals for 25 common biochemical properties. Scand J Clin Lab Invest 2004; 64: 271 - 84. [PubMed][CrossRef]

8. Parekh R, Care DA, Tainter CR. Rhabdomyolysis: advances in diagnosis and treatment. Emerg Med Pract 2012; 14: 1 - 15. [PubMed]

9. Renard D. Serum CK as a guide to the diagnosis of muscle disease. Pract Neurol 2015; 15: 121. [PubMed][CrossRef]

10. Giboney PT. Mildly elevated liver transaminase levels in the asymptomatic patient. Am Fam Physician 2005; 71: 1105-10. [PubMed]

11. Melli G, Chaudhry V, Cornblath DR. Rhabdomyolysis: an evaluation of 475 hospitalized patients. Medicine 2005; 84:377-85. [PubMed][CrossRef]

12. Bosch X, Poch E, Grau JM. Rhabdomyolysis and acute kidney injury. N Engl J Med 20o9; 361: 62 - 72. [PubMed][CrossRef]

13. Daniel RK, Ballard PA, Heroux P et al. High-voltage electrical injury: acute pathophysiology. J Hand Surg Am 1988; 13: 44 - 9. [PubMed][CrossRef]

14. Laufs U, Scharnagl H, Halle M et al. Treatment options for statin-associated muscle symptoms. Dtsch Arztebl Int 2015; 112: 748 - 55. [PubMed]

15. Beitland S, Moen H, Os I. Acute kidney injury with renal replacement therapy in trauma patients. Acta Anaesthesiol Scand 2010; 54: 833 - 40. [PubMed][CrossRef]

16. Vivino G, Antonelli M, Moro ML et al. Risk factors for acute renal failure in trauma patients. Intensive Care Med 1998; 24: 808 - 14. [PubMed][CrossRef]

17. Mikkelsen TS, Toft P. Prognostic value, kinetics and effect of CVVHDF on serum of the myoglobin and creatine kinase in critically ill patients with rhabdomyolysis. Acta Anaesthesiol Scand 2005; 49: 859-64. [PubMed][CrossRef]

18. Nance JR, Mammen AL. Diagnostic evaluation of rhabdomyolysis. Muscle Nerve 2015; 51: 793 - 810. [PubMed][CrossRef]

19. Brumback RA, Feeback DL, Leech RW. Rhabdomyolysis following electrical injury. Semin Neurol 1995; 15:329-34. [PubMed][CrossRef]

20. Zutt R, van der Kooi AJ, Linthorst GE et al. Rhabdomyolysis: review of the literature. Neuromuscul Disord 2014; 24: 651 - 9. [PubMed][CrossRef]

21. Vanholder R, Sever MS, Erek E et al. Rhabdomyolysis. J Am Soc Nephrol 20oo; 11: 1553 - 61. [PubMed]

Publisert: 12. juni 2018. Tidsskr Nor Legeforen. DOI: 10.4045/tidsskr.17.0613

Mottatt 14.7.2017, første revisjon innsendt 12.1.2018, godkjent 13.3.2018.

(C) Tidsskrift for Den norske legeforening 2020. Lastet ned fra tidsskriftet.no 